\title{
InBUy database of Invasive and Alien Species (IAS) in Uruguay: a useful tool to confront this threat to biodiversity
}

\author{
Silvana Masciadri ${ }^{1,2}$, Ernesto Brugnoli ${ }^{1}$ \& Pablo Muniz ${ }^{1}$ \\ ${ }^{1}$ Oceanología, Facultad de Ciencias, Universidad de la República, \\ Iguá, 4225, CP 11400, Montevideo, Uruguay \\ ${ }^{2}$ Corresponding author: Silvana Masciadri, e-mail: chivi@fcien.edu.uy
}

MASCIADRI, S., BRUGNOLI, E. \& MUNIZ, P. InBUy Database of Invasive and Alien Species (IAS) in Uruguay: a useful tool to confront this threat to biodiversity. Biota Neotrop. 10(4): http://www.biotaneotropica. org.br/v10n4/en/abstract?article+bn03910042010.

\begin{abstract}
In Uruguay, as well as in other regions of the world, IAS cause negative impacts on natural and managed ecosystems. The use of databases is a helpful tool to elaborate different strategies for prevention and control, and to develop policies and scientific analyses related to IAS. The database of IAS in Uruguay (InBUy) was developed during two time periods (2006-2007 and 2009-2010). It currently contains information on 33 specialists of different taxonomic groups, 14 research projects, 185 references, 351 species and 4,715 records, with vascular plants having both the highest number of species and records. Among vascular plants, herbaceous life forms are the most strongly represented, followed by trees and shrubs. Within animals, the fishes and mollusks are the most important groups. Analysis of the native distribution areas of IAS showed that most are indigenous from Europe, followed by Asia and Oceania. Data showed that introductions of IAS into Uruguay are mainly intentional (67\%), so efforts should be focused on policies and rules in order to control the entrance of exotic organisms and prevent new invasions. The geography of the compiled dataset shows the main impact is along the coastline, where the highest exotic species richness and records occurs, and also the most biological invasions. The InBUy database is up-to-date and has successfully contributed to the creation of an official IAS list for Uruguay and both a National and a Coastal Geographic Information System. It has also been used for developing consciousness about this important threat to biodiversity, at both national and regional scales.
\end{abstract}

Keywords: alien species, biological invasions, area of origin, cause of introduction, prevention.

MASCIADRI, S., BRUGNOLI, E. \& MUNIZ, P. La base de datos de Especies Exóticas e Invasoras (EEI) en Uruguay-InBUy: una herramienta útil para enfrentar esta amenaza sobre la biodiversidad. Biota Neotrop. 10(4): http://www.biotaneotropica.org.br/v10n4/es/abstract?article+bn03910042010.

Resumen: En Uruguay, al igual que en otras partes del mundo, las EEI han causado impactos negativos sobre los sistemas naturales y productivos. El uso de bases de datos a nivel mundial es una herramienta útil para elaborar estrategias de prevención y control, y para desarrollar políticas y análisis científicos en relación a las EEI. La base de datos de EEI en Uruguay (InBUy) fue desarrollada durante dos períodos (2006-2007 y 2009-2010). Actualmente contiene información de 33 especialistas de diferentes grupos taxonómicos, 14 proyectos de investigación, 185 referencias bibliográficas, 351 especies y 4715 registros, donde las plantas vasculares presentan el mayor número de especies y registros. Entre las plantas vasculares, las herbáceas son la forma de vida más representada, seguida por árboles y arbustos. Dentro de los animales, los peces y moluscos son los grupos más importantes. El origen geográfico de las EEI muestra que la mayoría son nativas de Europa, seguido por Asia y Oceanía. Los datos recabados muestran que la introducción de EEI a Uruguay es mayormente intencional (67\%), por tanto los esfuerzos deberían ser focalizados en políticas y reglamentaciones para controlar el ingreso de organismos exóticos y prevenir nuevas invasiones biológicas. Por otra parte, los datos muestran un impacto mayor sobre los ambientes costeros, donde fue registrado el mayor número de especies y registros, así como el mayor número de invasiones biológicas. Hasta la fecha, la base de datos InBUy ha contribuido exitosamente en la conformación de una lista oficial de EEI para Uruguay, y en la construcción de un Sistema Geográfico de Información Nacional y Costero. Asimismo, ha contribuido a la concientización a través de políticas de divulgación acerca de esta importante amenaza sobre la conservación de la biodiversidad, tanto a escala nacional como regional.

Palabras-clave: especies exóticas, invasiones biológicas, origen geográfico, causa de introducción, prevención. 


\section{Introduction}

Alien species are those distributed into geographical regions where they were not historically present, and are considered as new organisms in the ecosystem (Sax 2001). Invasive and Alien Species (IAS) are those that spread beyond their natural area of distribution to establish populations in new environments and cause, or have the potential to cause, harm (IUCN 2000, Valéry et al. 2008). Globalization and transport of natural resources has made it possible for species to travel through natural barriers and encroach on ecosystems, causing an important increment of the number of IAS around the world (Hulme et al. 2009). Hence, IAS have caused negative impacts on biological diversity, ecosystems, and human health, with ongoing important economic losses both in natural and managed systems (Morton 1997, IUCN 2000, Pimentel et al. 2000, D'Antonio et al. 2001, Matthews et al. 2005).

Biological invasions are considered at present the second most important cause of biodiversity loss in the world. Ecosystem services are not always perceived by human populations as highly important, but they are essential to human life, and IAS have negatively affected them (IUCN 2000). In Uruguay, as well as in other regions of the world, IAS have been introduced either accidentally or intentionally and cause negative impacts not only on natural ecosystems, but also on managed systems (Balero \& Gándara 2003, Ríos 2005, 2006, Brugnoli et al. 2006, Nebel \& Porcile 2006, Laufer et al. 2007, Lanfranconi et al. 2009).

The use of databases in the world has become a helpful tool to elaborate different strategies on prevention and control and/or to develop policies and scientific analyses related to IAS (APASD 2009, DAISIE 2009, GISD 2009, Hulme et al. 2009, USDA 2009). The information compiled in databases in the areas of taxonomy, ecology, introduction pathways, biogeographical origin and distribution, provide a quick source of information about IAS, to help with their management and control, as well as providing a basis to improve research and knowledge about them (Simpson et al. 2006, I3NIABIN 2010). The IAS information compiled in databases and made available on line allows the development of prevention plans not only at a national but also at regional or global scales. It also provides useful tools to policy makers for the development of strategies for IAS prevention and risk analyses derived from information compiled in the databases.
For this reason, researchers from the Faculty of Sciences of the University of Uruguay obtained financial support from the Invasives Information Network (I3N) of the Inter-American Biodiversity Information Network (IABIN), to develop a database of IAS in Uruguay (InBUy), during two periods of time (2006-2007 and 2009-2010). Thus, the aim of this paper is to analyze the information collected in the InBUy database and to explore the origin, taxonomy, distribution patterns and causes of introductions of IAS in Uruguay. The information generated has been useful for improving our national IAS strategy, developing management approaches and risk analysis policies, as well as creating research projects, both in national and regional scales.

\section{Material and Methods}

\section{Study site}

According to Cabrera \& Willink (1973), Uruguay is included in the Pampas phytogeographic province ( $32^{\circ} 30^{\prime} \mathrm{S}$ and $55^{\circ} 46^{\prime} \mathrm{W}$ ), a unique grassland ecosystem in South America (Figure 1). Here, the traditional productive systems are cattle/sheep grazing and agricultural crops. However, silviculture has recently been included as another agricultural activity, thus causing an open grassland ecosystem to change to a closed-canopy system with managed forestry, especially in the west, east and northeast of the country (Petraglia \& Dell'Acqua 2006). The coastal zone is characterized by estuarine and oceanic ecosystems, with the Río de la Plata Estuary and the Atlantic Ocean to the south and southeast respectively, where there is ca. $715 \mathrm{~km}$ of total extension of coastline. The harbour located at Montevideo city is one of the most important of the region and also is identified as a doorway for aquatic IAS (FREPLATA 2004).

\section{Data collection}

The database of IAS in Uruguay, named InBUy (Brugnoli et al. 2009), was based on a template developed by I3N (IABIN), at the Universidad del Sur (Gekko Group, Bahía Blanca, Argentina), Instituto Horus (Florianópolis, SC, Brazil), and TNC (The Nature Conservancy) during 2003-2005. The I3N database enables data inputs in a standard format (within an Access 2000 platform), enabling information sharing with other countries of the Americas. It

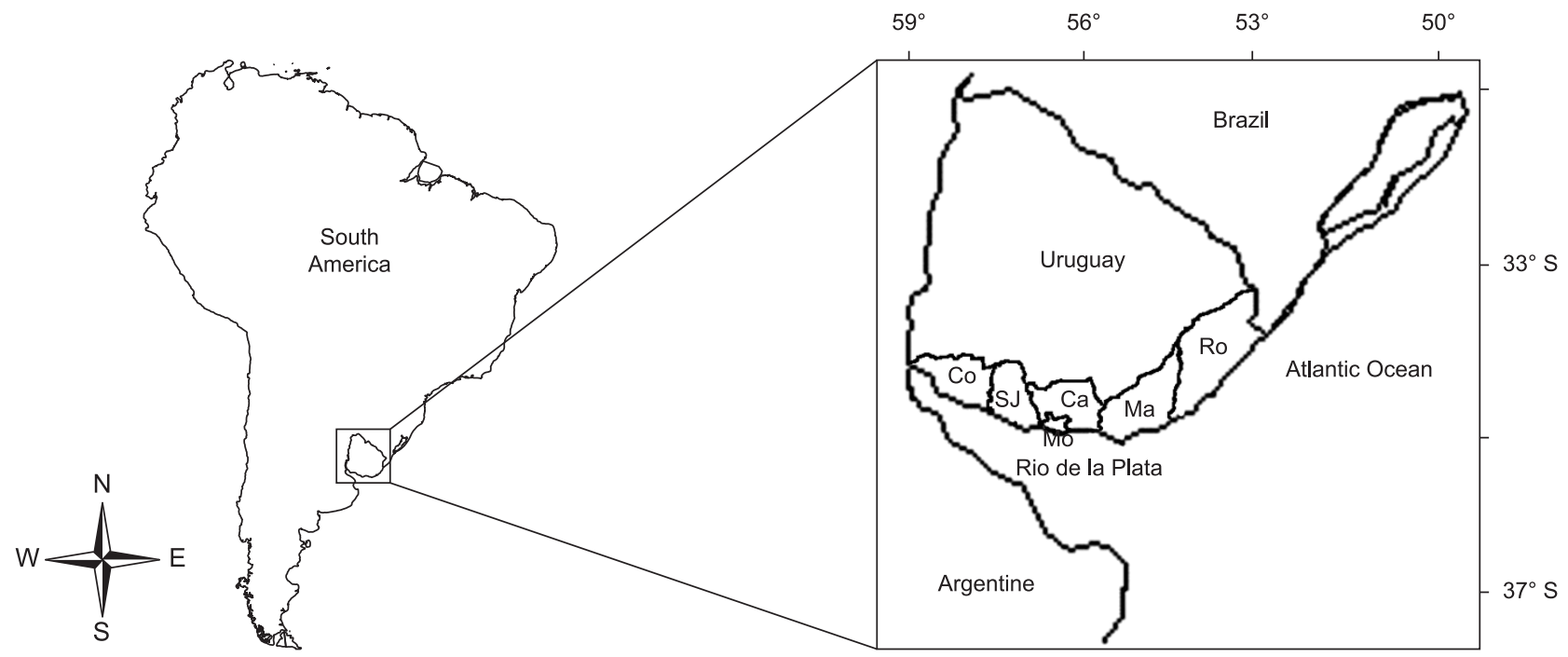

Figure 1. Uruguay's geographic location. Coastal departments are indicated from left to right as Co - Colonia; SJ - San José; Mo - Montevideo, the capital; Ca - Canelones; Ma - Maldonado, and Ro - Rocha. 
was adapted with specific controlled vocabulary for the habitats and political subdivisions (departments) of Uruguay. It has 58 items to complete, including taxonomic information, means of introduction, natural distribution, biological and ecological characteristics, type of impacts, control methods, specialists, related projects, references, and occurrences in Uruguay. The information collected consists of published and unpublished data; the latter being supplied by personal communications with specialists, or through academic theses or technical reports. Occurrence data of species are composed of exact records indicated by geographic coordinates, or estimated to the level of departments or cities in the case of species that are widely distributed in the country. The InBUy database at present is located online at http://www.uruguayi3n.iabin.net.

In order to analyze the whole dataset compiled in InBUy about IAS of Uruguay, the output of the complete database was organized by the number of species and records, their life form, natural distribution area at the continental level, taxonomic groups at different levels, and their cause of introduction (accidental or intentional).

\section{Results and Discussion}

\section{InBUy database}

At present InBUy contains information from 33 specialists of different taxonomic groups, 14 research projects, 185 bibliographic references, and 351 species and 4,715 occurrence records. Vascular plants having both the highest number of species (257) and records $(3,239)$, are followed by vertebrates (50 and 265) and Invertebrates (44 and 1,211).

Within vascular plants, herbaceous life forms are highly represented (139), followed by trees (90) and shrubs (19). There are also seven vines or climbers, one palm tree and one succulent. Among the herbaceous plants, Poaceae, Asteraceae and Fabaceae are the three most representative botanical families in InBUy (Figure 2a), being also the most important in the natural prairies of Uruguay (Figure 2b). Also, the number of vascular plant species in InBUy accounts for $11 \%$ of the native flora of Uruguay $(2,253)$ (Marchesi 2004). Many of these are forage species, especially referring to Poaceae and Fabaceae, and were introduced to create grazing prairies for livestock. The other most important families are related to therapeutic uses or associated with seed transport. Among trees, Myrtaceae and Pinaceae are the most represented families (Figure 3). These are used in silviculture, which has been promoted as an economic activity on Uruguayan prairies during the last 30 years. In silviculture, Eucalyptus and Pinus species are the most often planted (Petraglia \& Dell'Acqua 2006), although both are invasive in Uruguay and elsewhere in the region (INBIAR 2009, InBUy 2009, Instituto Horus 2009). In fact, diverse threats to the environment, human health and cultural aspects of the Pampas Biome were identified throughout a cooperation workshops among researchers of Argentina, Brazil and Uruguay, all related to landscape changes that silviculture is causing in the region (Guadagnin et al. 2009).

Within introduced animals, fishes are the most represented group, most of them being introduced for ornamental and aquacultural purposes (18 species). Mollusks are the next most important group (Figure 4). The native malacofauna of Uruguay includes 380 marine and estuarine species, 97 freshwater, and 42 terrestrial (Scarabino 2004). There are 17 terrestrial alien mollusk species recorded in InBUy, which represents $40 \%$ of the known terrestrial native species (Campos \& Calvo 2006). This value contrasts with the aquatic mollusks, where alien species recorded in InBUy are only $0.1 \%$ of the native ones. In spite of this great difference, the aquatic alien mollusks Limnoperna fortunei (Dunker, 1857), Corbicula fluminea
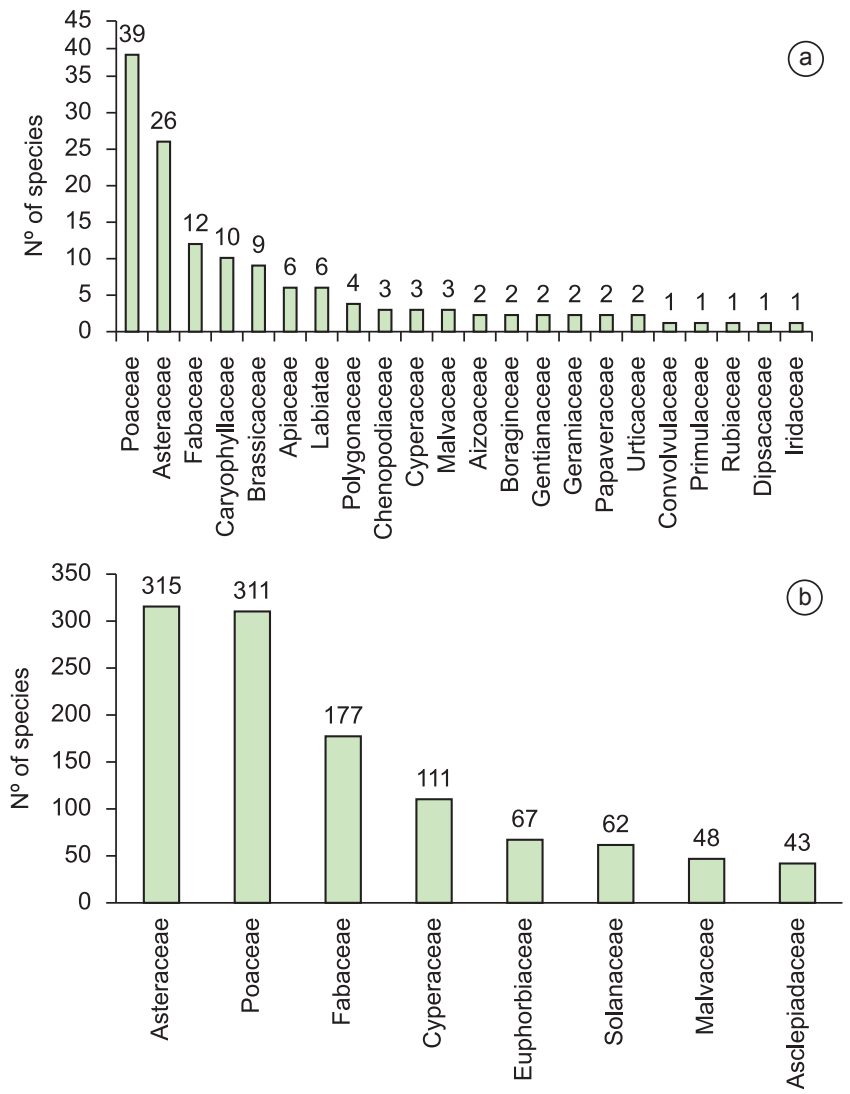

Figure 2. a) Number of herbaceous alien species in InBUy database, grouped by family; b) Number of most important herbaceous native species in Uruguay, grouped by family (modified from Marchesi 2004).

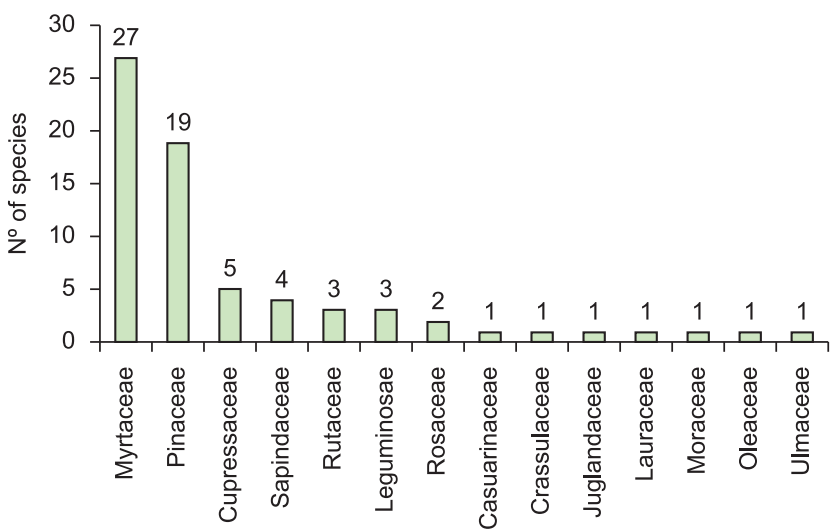

Figure 3. Number of alien trees species, grouped by family, in InBUy database.

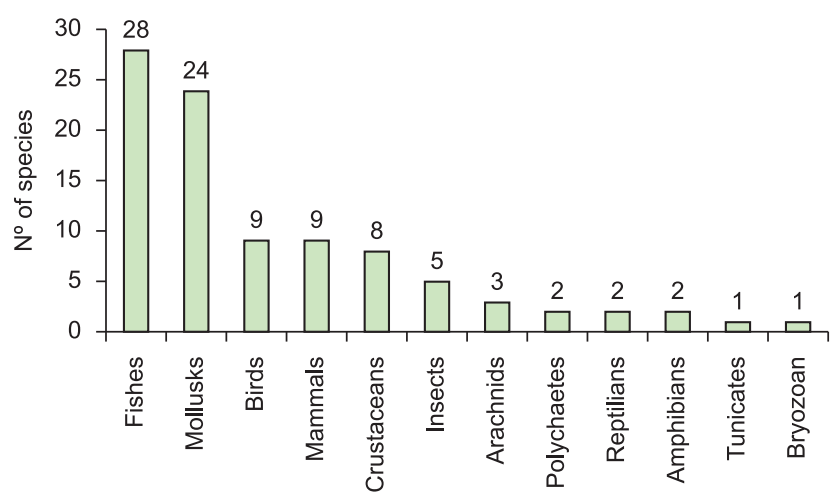

Figure 4. Animals classified by their life form in InBUy database. 
(Muller, 1774) and Rapana venosa (Valenciennes, 1846) that are present in Uruguay have a significant impact on biodiversity at global, regional and local scales (Scarabino 2004, Brugnoli et al. 2005, Karatayev et al. 2007, Carranza et al. 2009, Lanfranconi et al. 2009).

With regard to tetrapod vertebrates, birds and mammals are the most represented groups in InBUy, with nine species each one (Figure 4). Those values agree with the geographic distribution estimates for exotic mammals and birds between $30-35^{\circ}$ latitude by Sax (2001), where for the southern hemisphere 10 birds and 11 mammals were recorded. Tetrapod vertebrate native species include 446 birds, 124 mammals, 66 reptilians and 47 amphibians (Achaval 2009), and their aliens counterparts in InBUy represent $2,7,3$ and $2 \%$ of the native fauna, respectively. Despite the low percentage values, some of these vertebrate species, such as Sus scrofa (Linnaeus, 1758) (Lombardi et al. 2007) or Lithobates catesbeianus (Shaw, 1802) (Laufer et al. 2007), are very problematic because of their strong direct or indirect negative impacts on biological diversity and managed systems. Also, these species are included in the ' 100 of the World's Worst Invasive Species' list (ISSG 2004).

\section{Origin and cause of introduction}

The native distribution of IAS recorded in InBUy, classified by their geographic origin at a continental level, shows that most are indigenous to Europe, followed by Asia and Oceania (Figure 5).

This trend could be associated with commercial and cultural exchanges between the Río de la Plata and Eurasia, related to immigration events to South America (Río de la Plata Basin) since the beginning of the America conquest by Cristobal Colón, 500 years ago, and specifically to Solís, who arrived at the Río de la Plata in 1516. However, the major introductions of herbaceous IAS, the most abundant species life form recorded within InBUy, occurred during the second half of the 1800's, when farmers began cultivating prairies (Campal 1969). Later, the introduction of trees and shrubs started at the end of the 1800's and the beginning of the 1900's, and most were related to landscaping, gardening, and agroforestry (to a lesser extent). In the last 50 years, silvicultural practices have focused on alien species and increased the introduction of Pinus spp., Eucalyptus spp., Salix spp., and Populus spp., among others (Carrión et al. 1990, Petraglia \& Dell'Acqua 2006). Also, ornamental and commercial species have increased their introduction rates during this period, as a consequence of globalization and commercialization of gardening and crop species. The first exotic population influx to the Río de la Plata came from Europe, and was established in 1526 (ca. 500 years ago), though most IAS introductions date only from 150 years ago. In contrast, European civilization exists from $5300 \mathrm{BC}$, and there are database records of introductions of IAS to Europe from 500 years ago (Pyšek et al. 2003). This shows that IAS have been established in the Pampas region for a relatively brief period of time, when compared to Europe.

According to their causes of introduction, about $67 \%$ of Uruguayan IAS entered the country intentionally, due to their anticipated economic value as food, medicine, commercialization (mascots, ornamental plants), agriculture (aquaculture, silviculture, forage), soil fixation (dunes, railways) or other ecosystem services (Figure 6). The intentional introduction of alien species for aquaculture is also recent for the country, and dates from 1986 (Brugnoli et al. 2006). Such introductions were encouraged by government agencies during the 1990's, who promoted aquaculture with alien organisms (DINARA 2008). According to FAO, about $40 \%(1,386)$ of total new aquatic introductions $(3,141)$ result in a new pest (Perez et al. 2003). Aquatic IAS may produce negative impacts on native biodiversity, alterations in food webs and biological interactions, among others (Perez et al.
$2000,2003)$. Thus, it is very important to minimize the risks related to aquaculture practices caused by alien species, take into account the likelihood of strong negative biological consequences, and applying an early warning system (McNeely et al. 2001).

On the other hand, vertebrates (mainly fishes and amphibians) are the main taxa introduced for aquaculture $(76 \%)$. Many of them have been reported in other countries as important threats to biological diversity (Cyprinus spp., Oerochromis niloticus (Linnaeus, 1758), Lithobates catesbeianus (Shaw, 1802) (ISSG 2004). Current legislation does not require the use of sterile organisms in aquaculture, which means alien species that escape from aquaculture are generally able to freely reproduce in native environments. Nevertheless, recent decrees recommend the use of native species in aquaculture projects, and promote decisions based on scientific knowledge (DINARA 2008). In contrast, $90 \%$ of the ornamental fish species introduced in the country present tropical thermal tolerances (DINARA 2008) which restrict their survivability in the temperate aquatic ecosystems of Uruguay. The control and license of alien species introductions seems to be the main opportunity to avoid the entrance of new IAS. In this sense, a risk analysis could be a good tool to indicate which new introductions are undesirable (I3N-IABIN 2010).

About $12 \%$ of the alien species in InBUy were introduced accidentally. Aquatic mollusks are the most common group in this category. Many were introduced in ballast water due to increased trade between Asia and Argentina starting in the 1990's (Darrigran

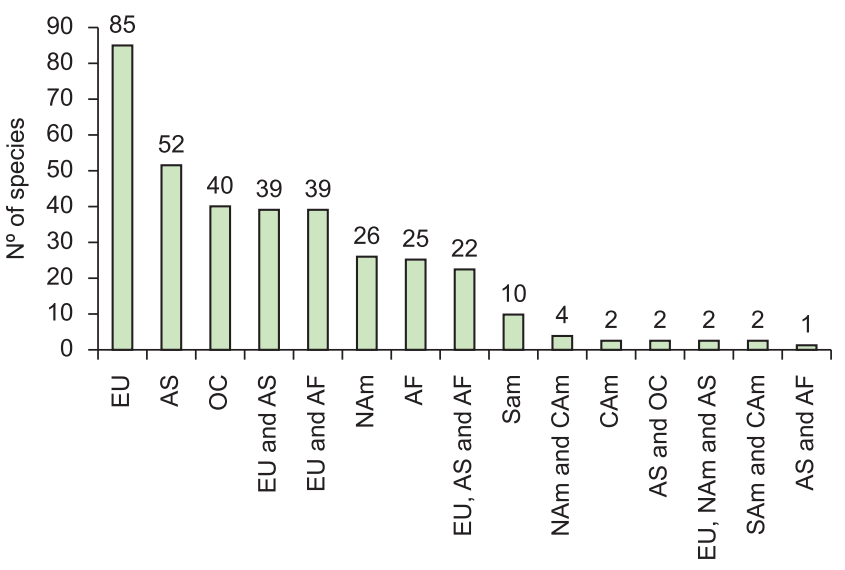

Figure 5. Number of IAS in Uruguay classified according to their geographic origin. Europe- EU; Asia- AS; Oceania- OC; Europe and Africa- EU and AF; Europa and Asia- EU and AS; Africa- AF; Europe, Asia and Africa- EU, AS and AF; North America- NAm; South America- SAm; Central America- CAm; Asia and Africa- AS and AF; Asia and Oceania- AS and OC; and Europe, North America and Asia- EU, NAm and AS.

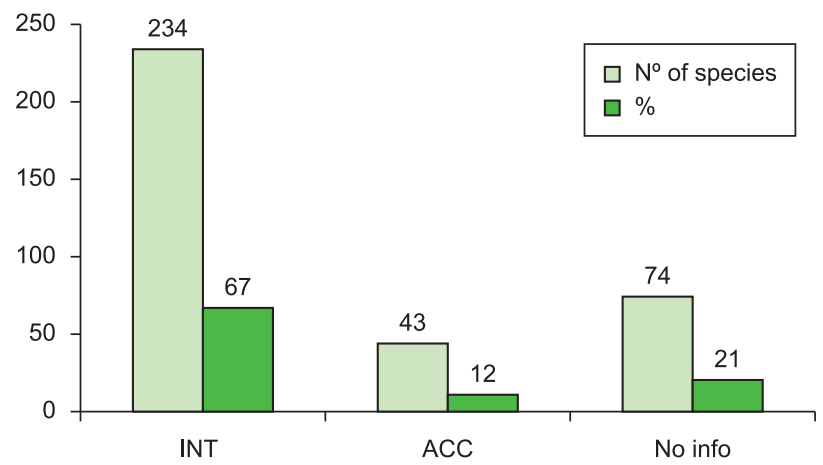

Figure 6. Number of IAS in Uruguay classified according to their type of introduction, expressed as total numbers and percentages. INT - intentional; ACC - accidental; and NO INFO - without confirmed information. 
\& Pastorino 1995). According to Brugnoli et al. (2006), in Uruguay 12 species of invertebrates were introduced accidentally through ballast water, including Limnoperna fortunei (Dunker, 1857) and Rapana venosa (Valenciennes, 1846). This number is lower than the introductions reported in other countries like Argentina, Brazil, Chile, and the United States. This could be due to little research on the taxonomy and ecology of aquatic IAS, or may be due to a lower intensity of maritime transport (Orensanz et al. 2002).

\section{Spatial distribution}

Data collected in InBUy show that the highest values of exotic species and records are along the southern coastline, from Colonia department at the southwest on the Río de la Plata and Uruguay Rivers, to Rocha department at the southeast on the Atlantic Ocean (Figure 1). Species and records distributed on the coast represent 96 and $69 \%$ of the total dataset, with 338 species and 3,288 records respectively. The capital city, Montevideo, has the highest number of species and records (256 and 1,535 respectively). Canelones shows the second highest values, which is the second largest populated department and is highly agricultural (Table 1). Most alien species inhabit manmade environments and are related to human populations around the world (Sax 2001). This is also true in Uruguay, where more than $70 \%$ of the population is distributed throughout the coastline departments (Defeo et al. 2008). However, data collection efforts and accessibility is more intense next to the capital than far from it, so in the northern regions, IAS could be underestimated.

Among species recorded at coastal localities (338), it can be observed that most are terrestrial (301) and only 37 are aquaticestuarine (Table 2). As in other geographic areas, the database shows that herbaceous vascular plants are the most representative group, followed by trees and shrubs. Fishes and mollusks are also the most abundant group of animals, followed by crustaceans, birds and mammals (Table 2).

IAS vascular plants are one of the main threats to coastal biodiversity (Panario \& Gutierrez 2006, Defeo et al. 2008). They have strong effects on dunes, by modifying the natural processes between the sea-continent interface. Dune fixation is promoted by IAS colonization, causing seashore erosion, leading to changes in the native community's structure and homogenized landscapes, which in turn leads to a decrease in habitats available for native flora and fauna. Contrary to exotic vegetation, native coastal plants are of paramount importance since they both build the dunes and grow on them, thereby preserving coastal morphology and playing a fundamental role in limiting beach erosion and the cumulative effect of waves and storms (Chebataroff 1973, Dillenburg et al. 1992, Seeliger 1992, Cordazzo \& Seeliger 1995).

These negative impacts caused by IAS on coastal environments affect their quality and their touristic attraction, too. It should be noted that $80 \%$ of the gross domestic product of coastal localities comes from summer tourism (Defeo et al. 2008), so economic losses due to IAS deserve special attention. Some of the more problematic IAS trees on coastal environments are eucalyptus, pines and acacias (Eucalyptus spp., Pinus spp., Acacia spp.), or herbs as Bermuda grass (Cynodon dactylon (L.) Pers.) or the cape fig (Carpobrotus edulis (L.) N.E. Br.) (Panario \& Gutierrez 2006, Brugnoli et al. 2009, Ríos et al. 2010). These have changed the native community structure, replacing indigenous species and affecting the whole ecosystem.

Aquatic alien species also were more common at Montevideo, where the harbor is located and considered an entryway for IAS. The other two departments with highest richness values are Canelones and Maldonado, which have aquaculture ventures based on alien species (Laufer et al. 2007, DINARA 2008). Finally, Rocha has the lowest value of aquatic IAS, possibly due to its lower urban and productive development.
Table 1. Number of IAS species and records in InBUy for the 19 departments of Uruguay. The top six departments are all coastal.

\begin{tabular}{lcc}
\hline Department & $\mathbf{N}^{\mathbf{0}}$ of species & $\mathbf{N}^{\mathbf{0}}$ of records \\
\hline Montevideo & 256 & 1535 \\
Canelones & 125 & 458 \\
Maldonado & 119 & 286 \\
Rocha & 90 & 191 \\
Colonia & 81 & 227 \\
San José & 73 & 244 \\
Soriano & 70 & 347 \\
Paysandú & 64 & 187 \\
Lavalleja & 56 & 111 \\
Florida & 54 & 233 \\
Cerro Largo & 50 & 131 \\
Río Negro & 48 & 130 \\
Rivera & 46 & 95 \\
Salto & 45 & 159 \\
Artigas & 44 & 126 \\
Tacuarembó & 40 & 80 \\
Durazno & 36 & 99 \\
Flores & 33 & 94 \\
Treinta y Tres & 29 & 65 \\
\hline
\end{tabular}

Table 2. Number of alien species occurring in coastal departments in InBUy, classified according to their life form and their terrestrial or aquatic-estuarine habitat.

\begin{tabular}{lccc}
\hline Life form & $\mathbf{N}^{\mathbf{0}}$ of species & Terrestrial & Aquatic-Estuarine \\
\hline Herbaceous & 136 & 136 & - \\
Trees & 89 & 89 & - \\
Fishes & 25 & - & 25 \\
Mollusks & 22 & 17 & 5 \\
Shrubs & 19 & 19 & - \\
Birds & 9 & 9 & - \\
Mammals & 8 & 8 & - \\
Climbers & 7 & 7 & - \\
Crustaceans & 7 & 3 & 4 \\
Insects & 4 & 4 & - \\
Arachnids & 3 & 3 & - \\
Amphibians & 2 & 2 & - \\
Algae & 1 & - & 1 \\
Palm trees & 1 & 1 & - \\
Polychaetes & 1 & 1 & - \\
Reptilians & 1 & 1 & - \\
Bryozoan & 1 & - & 1 \\
Succulent & 1 & 1 & - \\
Tunicates & 1 & - & 1 \\
Total & 338 & 301 & 37 \\
\hline
\end{tabular}

Although there are relatively few aquatic IAS, they are well established and include dangerous invaders such as the golden mussel (L. fortunei (Dunker, 1857)) and the rapa whelk (R.venosa (Valenciennes, 1846)). These are causing negative impacts on biological diversity, affecting industry by macrofouling, and collapsing fisheries, leading to important economical losses (Brugnoli et al. 2005, Carranza et al. 2009, Lanfranconi et al. 2009). Several projects were 
undertaken in the country in relation to these species (Clemente \& Brugnoli 2002, Muniz et al. 2005, Brugnoli et al. 2006), evaluating their negative effects on biodiversity (Orensanz et al. 2002, Scarabino 2004, Borthagaray et al. 2006) and addressing their spatial distribution and colonization along the hydrographic basins and coastal zones (Brugnoli et al. 2005, Langone 2005, Lanfranconi et al. 2009).

It is relevant to highlight that 62 of the 64 species recorded as invasive in InBUy (Table 3) are present at least at one locality along the coastal departments. The other two Cyperus iria L. (Cyperaceae) and Pterocarya rehderiana C.K.Schneid. (Juglandaceae) was registered in Artigas and Lavalleja Departments. Montevideo and Canelones exhibit again the highest invasive species richness values (42 and 48 respectively), but are closely followed by Maldonado and Rocha
(35 and 30), and San José and Colonia (22 and 24). Urbanization pressure, tourism activities and agriculture are the principal causes of most biological invasions recorded on the coastline.

\section{Final remarks}

The latest compiled dataset in InBUy showed the main IAS impact to be along the coastline, by both the presence of most species richness and records, and the more biological invasions recorded. The introduction of IAS in Uruguay has mainly been intentional, so regulations could be put into effect to prevent new invasions. Due to the fact that the costs of negative impacts, control and eradication of IAS can reach millions and billions of dollars (Pimentel et al. 2000), without any doubt prevention policies are the best strategy, with the

Table 3. Invasive species, their respective families, and their life form recorded in at least one locality in the InBuy database.

\begin{tabular}{|c|c|c|}
\hline Species & Family & Life form \\
\hline Acacia dealbata Link & Fabaceae & tree \\
\hline Acacia longifolia (Andrews) Willd. & Fabaceae & tree \\
\hline Acer negundo L. & Aceraceae & tree \\
\hline Arundo donax $\mathrm{L}$. & Poaceae & cane \\
\hline Asparagus asparagoides (L.) Druce & Asparagaceae & herb \\
\hline Asparagus densiflorus (Kunth) Jessop & Asparagaceae & herb \\
\hline Asparagus plumosus Baker & Asparagaceae & herb \\
\hline Carpobrotus edulis (L.) N.E. Br. & Aizoaceae & herb \\
\hline Coleostephus myconis (L.) Cass. & Asteraceae & herb \\
\hline Corbicula fluminea (Muller, 1774) & Corbiculidae & mollusk \\
\hline Cotoneaster franchetii Bois & Rosaceae & tree-shrub \\
\hline Cotoneaster pannosus Franch. & Rosaceae & tree-shrub \\
\hline Cotoneaster salicifolia Franch. & Rosaceae & tree-shrub \\
\hline Crassula multicava Lemaire & Crassulaceae & herb \\
\hline Cynodon dactylon (L.) Pers. & Poaceae & herb \\
\hline Cyperus esculentus L. & Cyperaceae & herb \\
\hline Cyperus iria $\mathrm{L}$. & Cyperaceae & herb \\
\hline Cyprinus carpio (Linnaeus, 1758) & Cyprinidae & fish \\
\hline Cyprinus carpius var. specularis (Linnaeus, 1758) & Cyprinidae & fish \\
\hline Cytisus monspessulanus $\mathrm{L}$. & Fabaceae & shrub \\
\hline Eragrostis plana Nees & Poaceae & herb \\
\hline Eucalyptus globulus Labill. & Myrtaceae & tree \\
\hline Ficopomatus enigmaticus (Fauvel, 1923) & Serpulidae & polychaeta \\
\hline Fraxinus americana $\mathrm{L}$. & Oleaceae & tree \\
\hline Fraxinus lanceolata Borkh. & Oleaceae & tree \\
\hline Gleditsia triacanthos $\mathrm{L}$. & Fabaceae & tree \\
\hline Hedera helix $\mathrm{L}$. & Araliaceae & climb \\
\hline Helenium amarum (Raf.) H. Rock & Asteraceae & herb \\
\hline Iris pseudacorus $\mathrm{L}$. & Iridaceae & herb \\
\hline Laurus nobilis L. & Lauraceae & tree \\
\hline Ligia exotica (Roux, 1828) & Ligiidae & crustacean \\
\hline Ligustrum lucidum W.T. Aiton & Oleaceae & tree \\
\hline Ligustrum sinense Lour. & Oleaceae & tree-shrub \\
\hline Limnoperna fortunei (Dunker, 1857) & Mytilidae & mollusk \\
\hline Lonicera japonica Thunb. ex Murray & Caprifoliaceae & climb \\
\hline Melia azedarach $\mathrm{L}$. & Meliaceae & tree \\
\hline Membraniporopsis tubigera (Osburn, 1940) & Flustridae & bryozoan \\
\hline Morus alba $\mathrm{L}$. & Moraceae & tree \\
\hline Mus musculus (Linneaus, 1758) & Muridae & mammal \\
\hline Myoporum laetum G. Forst. & Myoporaceae & tree-shrub \\
\hline
\end{tabular}


Table 3. Continued...

\begin{tabular}{|c|c|c|}
\hline Species & Family & Life form \\
\hline Neomysis americana (Smith, 1873) & Mysidae & crustacean \\
\hline Picris echioides L. & Asteraceae & herb \\
\hline Pinus elliottii Engelm. & Pinaceae & tree \\
\hline Pinus pinaster Ait. & Pinaceae & tree \\
\hline Pittosporum undulatum Vent. & Pittosporaceae & shrub \\
\hline Populus alba $\mathrm{L}$. & Salicaceae & tree \\
\hline Pterocarya redheriana C.K.Schneid. & Juglandaceae & tree \\
\hline Pyracantha coccinea M. Roem & Rosaceae & shrub \\
\hline Rapana venosa (Valenciennes, 1846) & Muricidae & mollusk \\
\hline Rapistrum rugosum (L.) All. & Brassicaceae & herb \\
\hline Rattus norvergicus (Berkenhout, 1769) & Muridae & mammal \\
\hline Rattus rattus (Linnaeus, 1758) & Muridae & mammal \\
\hline Ricinus communis L. & Euphorbiaceae & shrub \\
\hline Rubus fruticosus L. & Rosaceae & shrub \\
\hline Rubus ulmifolius Schott & Rosaceae & shrub \\
\hline Senecio vulgaris $\mathrm{L}$. & Asteraceae & herb \\
\hline Silene gallica $\mathrm{L}$. & Caryophyllaceae & herb \\
\hline Sorghum halepense (L.) Pers. & Poaceae & herb \\
\hline Spartium junceum L. & Fabaceae & shrub \\
\hline Styela plicata (Lesueur, 1823) & Styelidae & tunicate \\
\hline Sus scrofa (Linnaeus, 1758) & Suidae & mammal \\
\hline Tamarix gallica $\mathrm{L}$. & Tamaricaceae & tree \\
\hline Ulex europaeus L. & Fabaceae & shrub \\
\hline Ulmus minor Mill. & Ulmaceae & tree \\
\hline
\end{tabular}

lowest economic and environmental cost and risk (Hulme et al. 2009). Some methodologies have been developed to assess the risk and to prevent new introductions of alien species, through an early warning system (McNeely et al. 2001). In this sense, InBUy could be used as a solid baseline of information to address this challenge.

Although the eradication of IAS is very difficult and expensive, it is possible and also necessary to do it, and the more rapid response constitutes the best success to achieve the best results. This is the situation in the coastal departments of Uruguay, where economic losses related to IAS could directly affect the economic benefits received, and it is sorely needed in order to reduce the negative impacts on coastal ecosystems. Even so, natural systems are complex, therefore, control methods must be based on scientific knowledge, supervised, and monitored. In most cases, restoration of affected areas is also necessary. This first database of IAS for Uruguay, InBUy, aims to contribute the baseline information required to face this problem, not only at local or national levels but also at a regional level, to develop national and regional policies and help in government and management decision-making. These are also the main objectives of I3N-IABIN (Simpson et al. 2006).

Moreover, information about IAS in Uruguay that is organized in a database will enable a rapid response to face this problem. The database has been used by a National IAS Committee, which was first established in 2007 and it is coordinated by the National Environmental Agency (DINAMA). The committee consists of specialists from different government agencies, agriculture research institutes, and universities. Their objective is to create a national strategy to strengthen the national policies related to IAS prevention, detection, and control. Moreover, InBUy has been used by the Coastal Environmental Information System and by the ECOPLATA
Program (DINAMA), a project to support the integrated coastal zone management in Uruguay. As an up-to-date resource, the InBUy database has successfully contributed to an agreed IAS list for Uruguay, and to both National and Coastal Geographic Information Systems. It has also contributed to an increased conscientiousness about the problem through divulgation policies about this important issue, in order to collaborate with the biodiversity conservation community within the country and in the region, too.

\section{Acknowledgments}

We thank all the Uruguayan specialists for their contribution of quality data that generated the InBUy database, and those in charge of the herbaria MVJB and MVFA, for the permission to access and check information in those collections. We especially thank I3N-IABIN and EcoPlata for financial support, Demetrio Guadagnin, Sergio Zalba, Carlos Fonseca and the rest of the tri-national team of PROSUL (CNPq) for encouraging this paper, Andrea Grosse for her comments on the manuscript, Felipe García-Rodríguez and Annie Simpson for the English review and some useful remarks, and the anonymous reviewers who improve the manuscript with their comments.

\section{References}

ACHAVAL, F. 2009. Lista de los vertebrados del Uruguay. Zoología de Vertebrados. Facultad de Ciencias. http://zvert.fcien.edu.uy. (Accessed 8 Jul 2009).

APASED. 2009. National Institute for Agro-Environmental Sciences. http:// apasd-niaes.dc.affrc.go.jp/list/menu.php. Accessed 6 Jul 2009.

BALERO, R. \& GÁNDARA J.M. 2003. Respuesta de Ulex europaeus L. a la quema controlada. Tesis 3163. Facultad de Agronomía, Montevideo. $60 \mathrm{p}$. 
BORTHAGARAY, A., CLEMENTE, J., BOCCARDI, L., BRUGNOLI, E. \& MUNIZ, P. 2006. Impacto potencial de invasión de Ficopomatus enigmaticus (Polychaeta: Serpulidae) en la Laguna de Rocha, Uruguay. Pan-American Journal of Aquatic Science 1(1): 57-65.

BRUGNOLI, E., CLEMENTE, J., BOCCARDI, L., BORTHAGARAY, A., \& SCARABINO F. 2005. Update and prediction of golden mussel (Limnoperna fortunei): distribution in the principal hydrographic basin of Uruguay. Anais da Academia Brasileira de Ciências 77(2): 235-244.

BRUGNOLI, E., CLEMENTE, J., RIESTRA, G., BOCCARDI, L. \& BORTHAGARAY, A. 2006. Especies acuáticas exóticas en Uruguay: situación, problemática y gestión. In: Bases para la conservación y manejo de la costa uruguaya (R. Menafra, L. Rodríguez, F. Scarabino \& D. Conde, ed.). Graphis, Montevideo, p. 351-362

BRUGNOLI, E., MASCIADRI, S. \& MUNIZ, P. 2009. Base de datos de especies exóticas e invasoras en Uruguay, un instrumento para la gestión ambiental y costera. ECOPLATA, Montevideo.

CABRERA, A.L. \& WILLINK. A. 1973. Biogeografía de América Latina. Organización de Estados Americanos, Washington, US. Serie Biología, n.13.

CAMPAL, E.F. 1969. La Pradera. Nuestra Tierra 28:1-60.

CAMPOS, J. \& CALVO, A. 2006. Moluscos introducidos en Uruguay. Com. Soc. Malacol. Urug. 9:75-78.

CARRANZA, A., DE MELLO, C., LIGRONE, A., GONZÁLEZ, S., PÍRIZ, P., \& SCARABINO, F. 2009. Observations on the invading gastropod Rapana venosa in Punta del Este, Maldonado Bay, Uruguay. Biol. Inv. doi: 10.1007/s10530-009-9534-0.

CARRIÓN, J., MANTERO, C., OUINTILLÁN, A., TAMOSIUNAS, M., TUSET, R. 1990. El complejo forestal del Uruguay. Fac.de Agron. Montevideo.

CHEBATAROFF, J. 1973. Ambientes salinos; su vegetación. Facultad de Humanidades y Ciencias, Montevideo, 5: 1-36.

CLEMENTE, J.M. \& BRUGNOLI, E. 2002. Note: Record of Limnoperna fortunei (Dunker, 1857) (Bivalvia: Mytilidae) in continental waters of Uruguay (Río Negro and Río Yí). Boletín de la Sociedad Zoológica del Uruguay 13: 29-33.

CORDAZZO, C.V. \& SEELIGER, U 1995. Guia ilustrado da vegetaçâo costeira no extremo sul do Brasil. Río Grande: Fundaçâo do Rio Grande do Sul.

D’ANTONIO, C.M., MEYERSON, L.A. \& DENSLOW, J. 2001. Exotic species and conservation. In: Conservation biology: research priorities for the next decade (M.E. Soule \& G.H. Orains, ed.). Island Press, Washington, p.55-80.

DAISIE, 2009. Delivering alien invasive species inventories for europe. http:// www.europe-aliens.org/ (Accessed 8 Jul 2009).

DARRIGRAN, G. \& PASTORINO, G. 1995. The recent introduction of asiatic bivalve, Limnoperna fortunei (Mytilidae) in to South America. The Veliger 38:183-187.

DEFEO, O., VINCENT, P., ACUÑA, A., AMESTOY, F., DE ALAVA, A., CASTIÑEIRA, E., DELFINO, E., FAGÚNDEZ, C., GARCÍA OLASO, F., GARCÍA PÍNGARO, R., GUTIÉRREZ, O., HORTA, S., LAPORTA, P., MARIANOVICH, P., MARTÍNEZ, G., PANARIO, D., PASSADORE, C., PUIG, P., RÍOS, M., SZEPHEGYI, M.N. \& TRIMBLE, M. 2008. Zona Costera. In GeoUruguay (M. Gómez \& Martino D., cord.). Mosca, Montevideo, p.118-170.

DILLENBURG, L.R., WAECHTER, J.L. \& PORTO, M.L. 1992. Species composition and structure of a sandy coastal pain forest in northern Rio Grande do Sul, Brasil. In Coastal plants communities of Latin America (U. Seeliger, ed.). Academic Press, San Diego, p.349-366.

DINARA 2008. Plan nacional de desarrollo de la acuicultura. Estrategia general para el desarrollo de la acuicultura sostenible en la República Oriental del Uruguay. DINARA-FAO, Montevideo, 40p.

FREPLATA, 2004. Análisis diagnóstico transfronterizo del Río de la Plata y su frente marítimo. In Proyecto Protección Ambiental del Río de la Plata y su Frente Marítimo (A. Brazeiro, A. Carsen, M. Gómez, P. Himschot, C. Lasta, J. Oribe Stemmer, A. Perdomo \& H. Roche, ed.). PNUD-GEF, Montevideo. Documento técnico.
GISD, 2009. Global Invasive Species Database. Invasive Species Specialist Group http://www.issg.org/database. (Accessed 11 Aug 2009).

GUADAGNIN, D.L., ZALBA, S.M., COSTA-GORRIZ, B., FONSECA, C.R., NEBBIA, A.J., VILLALOBOS, A.E., EMER, C., SANHUEZA, C.C., WENDLAND, E., PERELLO, L.F.C., BASTOS, M.C.S., GERMAIN, P., MASCIADRI-BÁLSAMO, S. \& CUEVAS, Y.A. 2009. Árvores e arbustos exóticos invasores no bioma pampa - questões ecológicas, culturais e sócioeconômicas de um desafio crescente. In Campos do Sul do Brasil (S. Muller \& V.P. Pillar, ed.). Ministério do Meio Ambiente, Brasília, p. 300-316.

HULME, P.H., PYSEK, P., NENTWIG, W. \& VILÀ, M. 2009. Will Threat of Biological Invasions Unite the European Union? Science. 324:40-41.

IABIN. 2010. http://i3n.iabin.net/ (Accessed 20 Jul 2010).

INBIAR. 2009. I3N-Argentina. http://inbiar.org.ar/ (Accessed 03 Jul 2009).

INBUY. 2009. I3N-Uruguay. http://uruguayi3n.iabin.net/ (Accessed 01 Jul 2009).

INSTITUTO HORUS. 2009. I3N-Brasil http://institutohorus.org.br/ (Accessed 04 Jul 2009).

ISSG-IUCN. 2004. 100 of the World's Worst Invasive Alien Species. http:// www.issg.org/ (Accessed 04 Jul 2009).

IUCN. 2000. Guidelines for the prevention of biodiversity loss caused by alien invasive species. International Union for the Conservation of Nature, Gland, Switzerland.

KARATAYEV, A.Y., PADILLA, D., MINCHIN, D., BOLTOVSKOY, D. \& BURLAKOVA, L.B. 2007. Changes in global economies and trade: the potential spread of exotic freshwater bivalves. Biol. Inv. 9:161-180.

LANFRANCONI, A., HUTTON, M., BRUGNOLI, E. \& MUNIZ, P. 2009. New record of the alien mollusc Rapana venosa (Valenciennes 1846) in the Uruguayan coastal zone of Río de la Plata. Pan Am. J. of Aquat. Sci. 4(2):216-221.

LANGONE, J.A., 2005. Notas sobre el mejillón dorado Limnoperna fortunei (Dunker 1857) (Bivalvia, Mytilidae) en Uruguay. Museo Nacional de Historia Natural y Antropología, Montevideo, 1:1-18.

LAUFER, G., CANAVERO, A., NUÑEZ, D. \& MANEYRO, R. 2007. Bullfrog (Lithobates catesbeianus) invasion in Uruguay. Brief Communication. Biol. Inv. doi10.1007/s10530-007-9178-x.

Lombardi, R., Berrini, R., Achaval, F. \& Wayson, C. 2007. El Jabalí en el Uruguay. Centro Interdisciplinario para el Desarrollo. Montevideo.

MARCHESI, E. 2004. Flora y vegetación del Uruguay. In Informe Ambiental Resumen (C. Faroppa \& K. Annala, ed.). BOTNIA, Montevideo, p.1-8.

MATTHEWS, S., ZILLER, S., ZALBA, S., IRIARTE, A., BAPTISTE, M.P., de POORTER, M., CATTANEO, M., CAUSTON, C. \& JACKSON, L. 2005. Sudamérica invadida. El creciente peligro de las especies exóticas invasoras. GISP, Kirstenbosch.

McNEELY, J.A., MOONEY, H.A., NEVILLE, L.E., SCHEI, P. \& WAAGE, J.K. 2001. Global Strategy on Invasive Alien Species. IUCN on behalf of the Global Invasive Species Programme. IUCN, Cambridge.

MORTON, B. 1997. Freshwater fouling bivalves. Dissertation. First International Corbicula Symposysium University of Texas, p.1-14.

MUNIZ, P., CLEMENTE, J. \& BRUGNOLI, E. 2005. Benthic invasive pests in Uruguay: a new problem or an old one recently perceived? Marine Pollution Bulletin, 50: 1014-1018.

NEBEL, J.P. \& PORCILE, J.F. 2006. Contaminación del Bosque nativo por especies arbóreas y arbustivas exóticas. 27 p. http://www.mgap.gub.uy/ Forestal. Accessed 15 feb 2007.

ORENSANZ, J.M., SCHWINDT, E., PASTORINO, G., BORTOLUS, A., CASAS, G., DARRIGRAN, G., ELÍAS, R., LÓPEZ-GAPPA, J.J., OBENAT, S., PASCUAL, S., PENCHASZADEH, P., PIRIZ, M.L., SCARABINO, F., SPIVAK, E.D. \& Vallarino, E. 2002. No longer the pristine confines of the world ocean: a survey of exotic marine species in the southwestern Atlantic. Biol. Inv. 4:115-143.

PANARIO, D. \& GUTIERREZ, O. 2006. Dinámica y fuentes de sedimentos de las playas uruguayas. In Bases para la conservación y manejo de la costa uruguaya (R. Menafra, L. Rodríguez, F. Scarabino \& D. Conde, ed.). Graphis, Montevideo, p.21-34. 
PEREZ, J.E., ALFONSI, C., NIRCHIO, M., MUÑOZ, C. \& GÓMEZ, J.A 2003. The introduction of exotic species in aquaculture: a solution or part of the problem. Interciencia 28:234-238.

PEREZ, J.E., NIRCHIO, M. \& GÓMEZ, J.A. 2000. Aquaculture: part of the problem, not a solution. Nature 408:514.

PETRAGLIA, C. \& DELL'ACQUA M. 2006. Actualización de la carta forestal del Uruguay con imágenes del año 2004. MGAP, Montevideo.

PIMENTEL, D., LANCH, L., ZÚÑIGA, R. \& MORRISON, D. 2000. Environmental and economic cost of nonindigenous species in the United States. BioSci. 50:53-65.

PYŜEK, P., SÁDLO, J., MANDÁK, B. \& JARO'ŜÍK, V. 2003. Czech alien flora and the historical pattern of its formation: what came first to Central Europe? Oecologia 135:122-130.

RÍOS, A. 2005. Campaña para el control de la margarita de Piria. http:// www.inia.org.uy/publicaciones/documentos/le/ad/2005/. Accessed 15 May 2009.

RÍOS, A. 2006. Control de malezas en cultivo de Invierno. INIA La Estanzuela 7: 23-26.
RÍOS, M., BARTESAGHI, L., PINEIRO, V., GARAY, A., MAI, P., DELFINO, L., MASCIADRI, S., ALONSO-PAZ, A., BASSAGODA, M.J. \& SOUTULLO, A. 2010. Caracterización y distribución espacial del bosque y matorral psamófilo. ECOPlata-SNAP, Montevideo.

SAX, D.F. 2001. Latitudinal Gradients and Geographic Ranges of Exotic Species: Implications for Biogeography. J. of Biogeogr. 28:139-150.

SEELIGER, U. 1992. Coastal foredunes of southern Brazil: physiography, habitats and vegetation. In: Coastal plants communities of Latin America (U. Seeliger, ed.).: Academic Press, San Diego, p. 367-381.

SCARABINO, F. 2004. Conservación de la malacofauna uruguaya. Com. Soc. Malacol. Urug. 8:267-273.

SIMPSON, A., SELLERS, E., GROSSE, A. \& XIE, Y. 2006. Essential elements of online information networks on invasive alien species. Biol. Inv. 8:1579-1587.

VALÉRY, L., FRITZ, H., LEFEUVRE, J.C. \& SIMBERLOFF, D. 2008. In search of a real definition of the biological invasión phenomenon itself. Biol. Inv. 10: 1345-1351.

USDA. 2009. National invasive species information Center. http://www. invasivespeciesinfo.gov (Accessed 02 Jul 2009).

Received 22/06/2010

Revised 25/11/2010

Accepted 06/12/2010 
